\title{
Two pelobatid frogs from the late Miocene of Caucasus (Russia)
}

\author{
Elena V. Syromyatnikova
}

\begin{abstract}
Disarticulated remains of Pelobatidae are described from the late Miocene (early Turolian, MN 11) of the Volchaya Balka and the Gaverdovsky localities (Northern Caucasus, Russia). The records of both Pelobates and Eopelobates from the Volchaya Balka locality are the first late Miocene and the last doubtless record of their coexistence in the same area. The described Pelobates remains are characterized by a pustular type of cranial sculpture, which was known only in Pliocene-Recent forms. This record documents the appearance of the pustular sculpture in Pelobates as early as late Miocene, at least during the Vallesian-Turolian transition (about 9-8 m.y.).
\end{abstract}

Elena V. Syromyatnikova. A. A. Borissiak Paleontological Institute, Russian Academy of Sciences, Profsoyuznaya ul., 123, Moscow, 117997 Russia; Zoological Institute, Russian Academy of Sciences, Universitetskaya nab., 1, St. Petersburg, 199034 Russia. esyromyatnikova@gmail.com; sev@paleo.ru

Keywords: Anura; Eopelobates; late Miocene; Pelobates; Pelobatidae; Russia

Submission: 1 April 2017 Acceptance: 13 July 2017

\section{INTRODUCTION}

The Pelobatidae are a small group of anurans comprising two genera (sensu Frost et al., 2006): Pelobates Wagler, 1830 (Oligocene-Recent of Europe; Recent of Northern Africa and the Middle East) and Eopelobates Parker, 1929 (Eocene of North America; Eocene-Pliocene of Europe). Nevertheless, the systematics of Pelobatidae and relationships within the group are still a matter of discussion (e.g., Gao and Chen, 2017). Pelobates has a rich fossil record consisting of isolated bones and articulated fossils of various ontogenetic series from tadpoles to adults, whereas Eopelobates rarely occurs (Estes, 1970; Špinar, 1972; Roček, 1981; Sanchiz, 1998; Roček and Rage, 2000; Maus and Wuttke, 2002, 2004; Rage and Roček, 2003; Roček, 2013; Roček et al., 2014, and others).

Pelobates fossils have been reported from many European localities from the middle Oligocene to the Pleistocene. Currently, four extant ( $P$. cultripes, P. fuscus, P. syriacus, and P. varaldii) and four fossil (P. decheni, P. fahlbuschi, P. praefuscus, and $P$. sanchizi) species, as well as numerous indeterminate remains are known (e.g., Sanchiz, 1998; Roček and Rage, 2000; Rage and Roček, 2003; Roček, 2013, Roček et al., 2014).

Syromyatnikova, Elena V. 2017. Two pelobatid frogs from the late Miocene of Caucasus (Russia). Palaeontologia Electronica 20.2.36A: 1-12

palaeo-electronica.org/content/2017/1949-miocene-pelobatids-of-caucasus

Copyright: July 2017 Palaeontology Association. This is an open access article distributed under the terms of Attribution-NonCommercial-ShareAlike 4.0 International (CC BY-NC-SA 4.0), which permits users to copy and redistribute the material in any medium or format, provided it is not used for commercial purposes and the original author and source are credited, with indications if any changes are made.

creativecommons.org/licenses/by-nc-sa/4.0/ 
Eopelobates is known in the Oligocene and Miocene of Europe, where it is represented by four species (E. anthracinus, E. bayeri, E. hinschei, and E. wagneri) and in the Eocene of North America ( $E$. deani and E. grandis) (Roček et al., 2014). Among them, E. bayeri has the broadest geographic and temporal range, being known from the early Oligocene of Belgium, the late Oligocene-early Miocene of the Czech Republic, and the middle Miocene of Slovakia. In Europe, during the Miocene, Eopelobates began to be gradually replaced by Pelobates (Roček, 2013), which makes the Miocene period the most interesting interval in their history. It seems that Eopelobates disappeared during the Pliocene; some poorly preserved, isolated bones were recovered from this time interval (Młynarski, 1961, 1962; Sanchíz and Mlynarski, 1979; Hodrová, 1981). The last unambiguous occurrence is known from early Pliocene Osztramos 1 fauna, Hungary (Venczel, 2001). The Pliocene and Pleistocene pelobatids are represented by forms which are close to extant Pelobates species (Roček et al., 2014).

Although Eopelobates and Pelobates cooccurred in Europe from the middle Oligocene until the Pliocene (Roček, 2013), they are rarely found at the same localities. The presence of Eopelobates together with the Pelobates has been reported from the late Oligocene (Rott; Böhme et al., 1982) and early-middle Miocene (Sandelzhausen; Böhme, 2010) of Germany, Pliocene of Poland (Węże 1 and Rębielice Królewskie 1; Młynarski, 1977; Sanchíz and Mlynarski, 1979), Slovakia (Ivanovce; Hodrová, 1981), and Ukraine (Dolinskoe; Ratnikov, 2002).

Here we describe fragmentary remains of Pelobatidae from the nearly synchronous sites of Volchaya Balka and Gaverdovsky (late Miocene, lower Turolian, MN 11; Northern Caucasus, Russia), including records of both Eopelobates and Pelobates from Volchaya Balka locality, as well as some other remains of Pelobates sp. (Gaverdovsky locality) and Pelobatidae indet. (Volchaya Balka and Gaverdovsky localities).

\section{MATERIAL AND METHODS}

In addition to the specimens of Pelobatidae described below, this study relies on published data on the following fossil species of Eopelobates: E. grandis Zweifel, 1956, late Eocene of USA (Zweifel, 1956; Estes, 1970; Henrici, 2002; Roček et al., 2014); E. hinschei (Kuhn, 1941), middle Eocene of Germany (Estes, 1970; Sanchiz, 1998; Roček et al., 2014); E. wagneri (Weitzel, 1938), middle Eocene of Germany (Sanchiz, 1998; Wuttke, 2012; Roček et al., 2014); E. anthracinus Parker, 1929, late Oligocene of Germany (Estes, 1970; Špinar and Roček, 1984; Roček et al., 2014); E. bayeri Špinar, 1952, early Oligocenemiddle Miocene of Western and Central Europe (Špinar, 1952, 1972; Estes, 1970; Hodrová, 1981, 1988; Roček et al., 2014), E. deani Roček, Wuttke, Gardner and Bhullar, middle Eocene of USA (Roček et al., 2014), and Pelobates: P. fahlbuschi Böhme, 2010, early Miocene of Germany (Böhme, 2010); P. sanchizi Venczel, 2004 and P. cf. sanchizi, early-late Miocene of Hungary, Austria and Czech Republic (Venczel, 2004; Ivanov, 2008; Venczel and Hír, 2013; Böhme and Vasilyan, 2014); P. decheni Troschel, 1861, late Oligocene of Germany (Böhme et al., 1982; Roček and Wuttke, 2010); and $P$. praefuscus Khosatzky, 1985, early Pliocene of Moldavia (Khosatzky, 1985).

In addition, literature data and comparative material (dry skeletons) from the Paleoherpetological collection of the Zoological Institute, Russian Academy of Sciences (St. Petersburg, Russia) on Recent Pelobatidae was used.

The remains of Pelobatidae were collected in

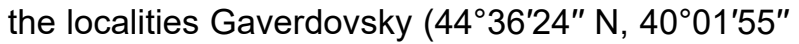
E) and Volchaya Balka (= Fortepianka) $\left(44^{\circ} 36^{\prime} 29^{\prime \prime}\right.$ $\mathrm{N}, 40^{\circ} 00^{\prime} 59^{\prime \prime} \mathrm{E}$ ) on the opposing banks (right and left, correspondingly) of the Belaya River, near the Gaverdovsky settlement, Maykop District, Republic of Adygea, Russia. Both localities were sampled from 2011 to 2013 by the joint field team of the Geological Institute of RAS (Moscow, Russia) and the Institute of Arid Zones SSC RAS (Rostov-onDon, Russia). The Gaverdovsky and Volchaya Balka localities produced a diverse vertebrate and mollusk fauna (Tesakov et al., 2013, in press; Syromyatnikova, 2016; Vinarski and Frolov, 2016). The micromammal assemblages of both localities studied by Tesakov et al. (2013) enabled their correlation to MN 11 unit of the European continental scale.

The SEM photographs were taken with Cambridge CamScan-4 in the Paleontological Institute of the Russian Academy of Sciences (Moscow, Russia). The morphological terminology of anuran bones used here was introduced by Bolkay (1919) and Roček (1981). The Pelobatidae material described is deposited in the Geological Institute of the Russian Academy of Sciences, Moscow (GIN hereafter) under collection numbers 1143 (Volchaya Balka locality) and 1144 (Gaverdovsky locality). 


\section{SYSTEMATIC PALAEONTOLOGY}

Order ANURA Fischer, 1813

Family PELOBATIDAE Bonaparte, 1850

Genus EOPELOBATES Parker, 1929

Type Species. Eopelobates anthracinus Parker, 1929, by monotypy.

\section{Eopelobates aff. Eopelobates bayeri} Figures 1-2

Material. Volchaya Balka locality: two frontoparietals (GIN 1143-200, 201); 10 maxillae (GIN 1143202-211); nine presacral vertebrae (GIN 1143-
212-220); one sacral vertebra (GIN 1143-221); one ilium (GIN 1143-222).

Description. The frontoparietal (Figure 1.1-4) is represented by two posterolateral fragments of the bone. The dorsal surface of the frontoparietal complex is flat and covered by small and rounded shallow pits, which are bordered by smooth ridges (= pit-and-ridge sculpture sensu Roček et al., 2014) located along the posterolateral margin of the bone. The median portion of the frontoparietal is unsculptured. The lateral margin of the dorsal, sculptured surface is nearly straight, does not extend laterally into the tectum supraorbitale and
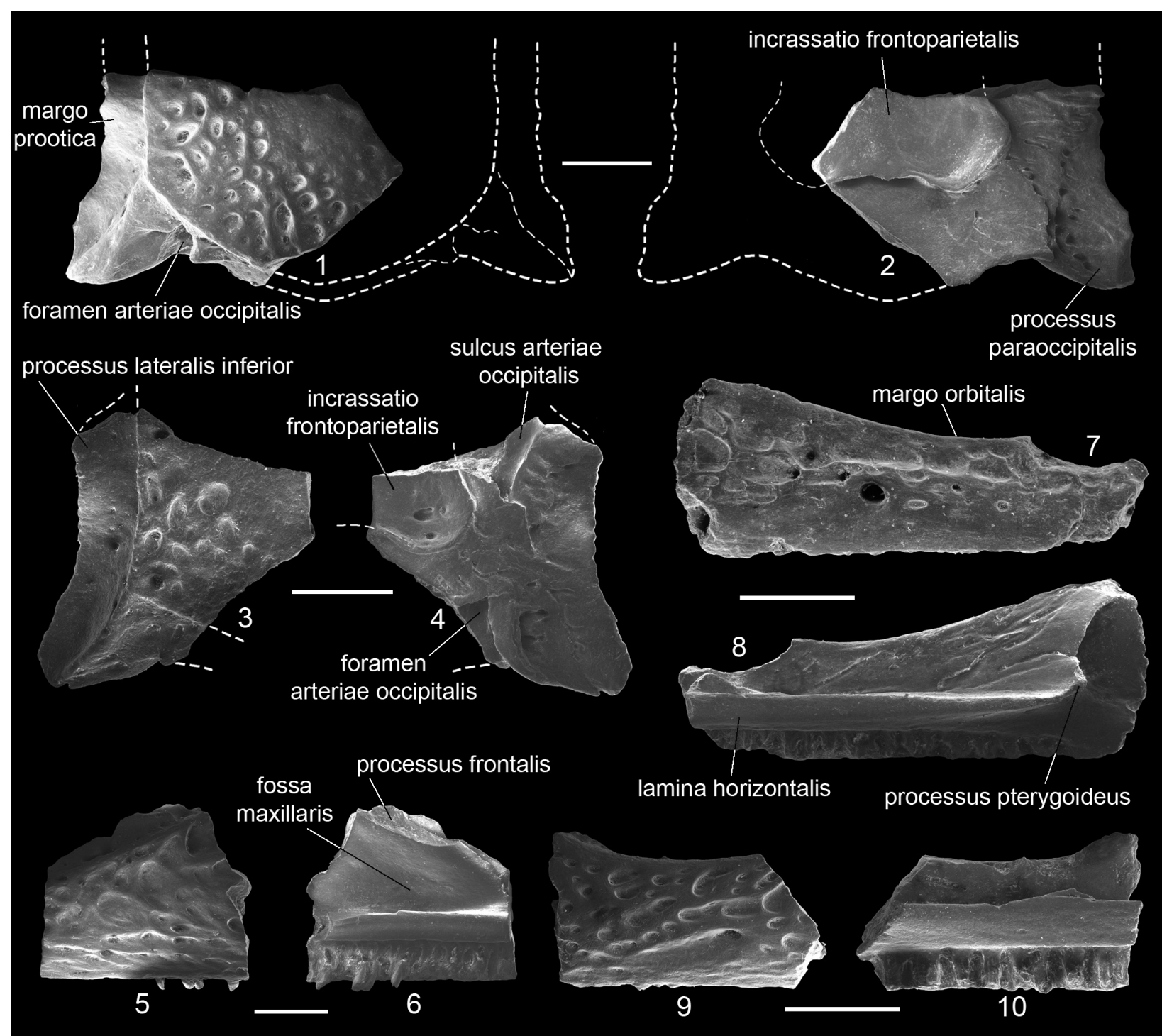

lamina horizontalis

processus pterygoideus

FIGURE 1. Eopelobates aff. E. bayeri from Volchaya Balka locality, Russia (late Miocene, early Turolian). 1-2, frontoparietal (GIN 1143-200) in dorsal (1) and ventral (2) views; 3-4, frontoparietal (GIN 1143-201) in dorsal (3) and ventral (4) views; 5-6, right maxilla (GIN 1143-202) in labial (5) and lingual (6) views; 7-8, right maxilla (GIN 1143-203) in labial (7) and lingual (8) views; and 9-10, ?left maxilla (GIN 1143-204) in labial (9) and lingual (10) views. Scales equal 1 $\mathrm{mm}$. 


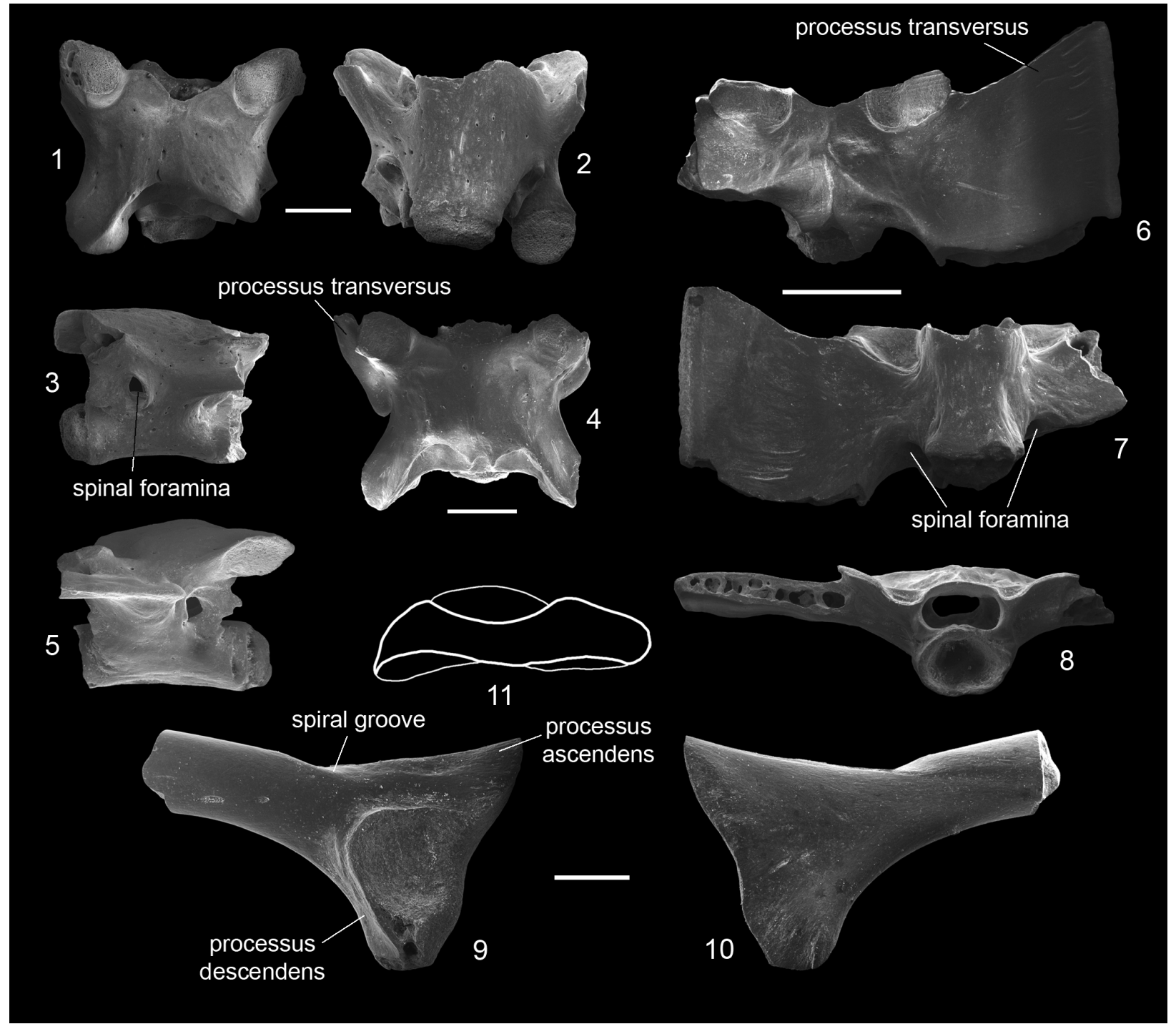

FIGURE 2. Eopelobates aff. E. bayeri from Volchaya Balka locality, Russia (late Miocene, early Turolian). 1-3, presacral vertebra (GIN 1143-212) in dorsal (1), ventral (2), and lateral (3) views; 4-5, presacral vertebra (GIN 1143-213) in dorsal (4) and lateral (5) views; 6-8, sacral vertebra (GIN 1143-221) in dorsal (6), ventral (7), and anterior (8) views; and 9-11, left ilium (GIN 1143-222) in lateral (9) and medial (10) views, and outline of the junctura ilioischiadica in caudal view (11). Scales equal $1 \mathrm{~mm}$.

was not in contact with the squamosum. Anteriorly, it shows a partly broken processus lateralis inferior. The margo prootica is slightly concave. The posterolateral part of the frontoparietal forms a welldeveloped paraoccipital process $(=$ processus paraoccipitalis), which is distally obtuse. It bears the foramen arteriae occipitalis, which is placed medially to the base of the paraoccipital process and is not hidden in dorsal view. Laterally, the foramen is bordered by small crests. The medial one is triangular and extended slightly beyond the posterior margin of the frontoparietal. The posterior border of the bone was convex. Ventrally, the frontoparietal surface is slightly concave. Only the posterolateral part of the frontoparietal incrassation (= incrassatio frontoparietalis) is visible. It has welldelimited margins and the posterior one is slightly concave. There is a deep groove situated on the anterior border of the processus lateralis inferior in the specimen GIN 1143-201 (Figure 1.4), representing the sulcus arteriae occipitalis.

The maxilla (Figure 1.5-10) is represented mostly by various central parts of the bone, lacking the processus posterior and lamina anterior (= rostellum). All the specimens are fully covered by sculpture, which is similar to that of the frontoparietal. In some areas the pits are anteroposteriorly elongated and may partially coalesce. The zygo- 
maticomaxillar process (= processus zygomaticomaxillaris) is not preserved. The margo orbitalis is deeply concave. The processus frontalis is partly exposed and projects at an oblique angle. The fossa maxillaris is relatively shallow. The lamina horizontalis is wide and projects lingually. It terminates in a wide and short pterygoid process (= processus pterygoideus). The tooth row reaches the posterior termination of the horizontal lamina or only slightly extends behind it.

The vertebrae (Figure 2.1-8) are represented by several incomplete presacrals and one fragmentary sacrum. The presacral vertebrae (Figure 2.1-5) are procoelous with elongated and cylindrical centra. Their neural arches in dorsal view are anteroposteriorly elongated and flattened, not imbricated. Anteriorly they are variously concave, posteriorly only two vertebrae form a very short pointed median process. The transverse processes (= processus transversus) are partly preserved only in two vertebrae. These vertebrae bear thin and anteriorly inclined transverse processes, which indicates that they come from the posterior section of the presacral region. In both lateral views, the neural arches of all presacral vertebrae surround the large spinal foramina.

The sacral vertebra (Figure 2.6-8) consists of a long procoelous centrum, neural arch, and incomplete right transverse process. The cotyle is deep and circular. The condyle is cylindrical and well outlined. It is not fused with the urostyle. The neural canal is dorsoventrally compressed. The transverse processes are incomplete, but reconstructed as a broadly dilated. The prezygapophyses are well developed and extended laterally. Because the posterior part of both sacral wings is broken off it cannot be decided whether there was a sign of an additional transverse process of the first caudal vertebra, which is marked by a ledge on the impression of Eopelobates anthracinus (see Roček et al., 2014, fig. 2d). In the lateral and posterior views, the large spinal foramina are visible.

The all ilia (Figure 2.9-11) are fragmentary. They lack the tuber superior and the iliac crest. The acetabular region is nearly triangular. The processus ascendens is relatively wide, whereas the processus descendens is short, slightly concave anteriorly. The spiral groove is relatively poorly developed. The medial surface of the acetabular region is only slightly striated and the interiliac synchondrosis is undeveloped.

Comments. The described elements are assigned to Eopelobates based on the sculpture of the frontoparietal and maxilla developed as small shallow pits (= pit-and-ridge pattern) and absence of frontoparietal-squamosal contact. The pit-and-ridge sculpture is also characteristic of the Oligo-Miocene Pelobates clade (sensu Venczel, 2004), where it consists of well-marked pits and ridges, contrary to relatively smooth and shallow pits and ridges in Eopelobates. In addition, the frontoparietals GIN 1143-200 and GIN 1143-201 are not ornamented along the midline, which is typical for Eopelobates. The flat dorsal surface of the described frontoparietal is also in contrast to those of most Pelobates species (except an undescribed species from the middle Miocene of Petersbuch 38; Böhme, 2010), which have a convex dorsal surface. The morphology of vertebrae in Caucasian frog points to both Eopelobates and OligoMiocene Pelobates. The spinal nerve foramina in presacral vertebrae are known in Eopelobates and in the Oligo-Miocene Pelobates. The condition of sacral vertebra, i.e., its fusion or not with the urostyle, varies in Pelobates, but these elements are generally fused in the Recent Pelobates species and free in Eopelobates and Oligo-Miocene Pelobates. The morphology of the described ilium (shallow spiral groove between the iliac shaft and acetabulum and poorly developed interiliac synchondrosis) also points to Eopelobates rather than to the Pelobates.

Currently, four species of Eopelobates are known in Europe and only one of them (E. bayeri) survived into the Miocene. Eopelobates from Volchaya Balka differs from $E$. anthracinus by sculpture of the frontoparietal consisting of small pits, and is similar to $E$. bayeri and E. hinschei in having the greater part of the maxilla sculpture covered. But it differs from $E$. bayeri in the free sacral vertebra (fused with urostyle in $E$. bayeri). But, within the material assigned to $E$. bayeri, a variation may exist with respect to the sacro-urostylar connection-by a concrescence, or by a joint (Estes, 1970; Hodrová, 1988). All known species of Eopelobates are preserved as flattened skeletons, thus the fragmentary remains of Eopelobates from Volchaya Balka cannot be undoubtedly determined to a species level. Taking into consideration the chronological proximity (Miocene) of E. bayeri and Eopelobates from Volchaya Balka, we tentatively attribute the latter to Eopelobates aff. E. bayeri. At the same time, Eopelobates from Volchaya Balka is highly similar to Eopelobates sp. from the late Miocene of Suchomasty (Hodrová, 1987a) in shape of posterolateral part of the frontoparietal and frontoparietal incrassation, and sculpture. Thus, Eopelobates from Volchaya Balka and Eope- 
lobates sp. from Suchomasty may belong to a same form.

Genus PELOBATES Wagler, 1830

Type species. Bufo fuscus Laurenti, 1768, by subsequent designation.

\section{Pelobates sp.}

Figure 3.1-11

Material. Volchaya Balka locality: two frontoparietals (GIN 1143-223, 224); six maxillae (GIN 1143225-230); one presacral vertebra (GIN 1143-231), one sacral vertebra (GIN 1143-232). Gaverdovsky locality: two maxillae (GIN 1144-200), one sacral vertebra (GIN 1144-201).

Description. The frontoparietals (Figure 3.1-2) are represented by the two posterolateral fragments of the bone. Dorsally, the bone is covered by a sculpture consisting of prominent isolated tubercles (= pustular sculpture sensu Roček et al., 2014), which is characteristic of the Pliocene-Recent Pelobates. The posterolateral part of the frontoparietal extends to the well-developed paraoccipital process, which is pointed distally. Dorsally, the process bears two sharp ridges. Anteriorly to the paraoccipital process, the dorsal sculptured surface of the bone extends laterally above the paraoccipital process which indicates the presence of the well-developed tectum supraorbitale. The foramen arteriae occipitalis is located medially to the base of the paraoccipital process and hidden in dorsal view by the base of the medially placed sharp ridge on the paraoccipital process. There is no additional foramen on the paraoccipital process, which is known in P. sanchizi (Venczel, 2004; Böhme and Vasilyan, 2014).

The maxilla (Figure 3.3-6) is represented by several posterior parts. As in the case of the frontoparietal, all the specimens are fully covered by sculpture consisting of prominent isolated tubercles (= pustular sculpture). The zygomaticomaxillar process and pterygoid process are not preserved. The margo orbitalis is deeply concave. The lamina horizontalis greatly projects lingually and widens near the middle part of the bone.

The single vertebra (Figure 3.7-9) is represented by the posterior presacral vertebra. Its centrum is procoelous and elongated. On the left side, it bears a long, cylindrical, and anteriorly directed transverse process. The neural arch in dorsal view is concave anteriorly and forms a pointed median process posteriorly, which seems to be longer than those of Eopelobates aff. E. bayeri (see above). In the lateral view, the neural arch lacks the spinal foramen on both sides.
The sacral vertebra (Figure 3.10-11) is seriously damaged, but it is clear that it was completely fused to the urostyle. The cotyle of the sacral vertebra is deep and circular. The neural canal is wide and dorsoventrally compressed. The transverse processes are broken off at their bases. Dorsally, the sacral vertebra and preserved portion of the urostyle are smooth, without a neural spine. The urostyle bears longitudinal lateral laminae which are confluent with sacral wings.

Comments. Pelobates remains from Volchaya Balka and Gaverdovsky can be assigned to the group of the Pliocene-Recent Pelobates species (sensu Venczel, 2004) based on the sculpturing of the frontoparietal and maxilla with prominent isolated tubercles (= pustular pattern). In Miocene Pelobates the sculpturing is a pit-and-ridge type (Oligo-Miocene forms) or transitional between those pit-and-ridge and pustular patterns (in some Miocene forms) (Venczel, 2004; Roček et al., 2014). Pelobates from Volchaya Balka differs from the Oligocene-Miocene Pelobates and Eopelobates in having the presacral vertebrae without spinal foramina and sacral vertebra fused to urostyle. These two characters are the same as in PlioceneRecent Pelobates. Within this species group, the urostyle is fused to the sacrum in $P$. fuscus and $P$. syriacus, whereas in $P$. cultripes and $P$. varaldi these two elements are frequently free (Bailon, 1991, 1999). The position of the foramen arteriae occipitalis in Pelobates from Volchaya Balka is consistent with that of $P$. cultripes, $P$. syriacus, and $P$. sanchizi, where this foramen is visible only in posterior view (Bailon, 1999; Venczel, 2004). The described Pelobates remains are too fragmentary and are not diagnostic at the species level. This is why we refer it to Pelobates sp.

\section{Pelobatidae indet.}

Figure 3.12-15

Material. Volchaya Balka locality: four scapulae (GIN 1143-233-236); four ilia (GIN 1143-237-240). Gaverdovsky locality: one premaxilla (GIN 1144202).

Description. The premaxilla (Figure $3.12-13$ ) is almost complete. The outer surface of the bone is smooth. The pars facialis has a narrow base and is situated near the midlength of the horizontal part of the bone (= pars dentalis). This process is relatively narrow and moderately tall, its distal portion is directed laterally. The dorsal end of the pars facialis terminates in a rounded point. From the medial surface the pars facialis is widely convex. The pars dentalis is nearly straight. The number of tooth positions on the premaxilla is 11 . 


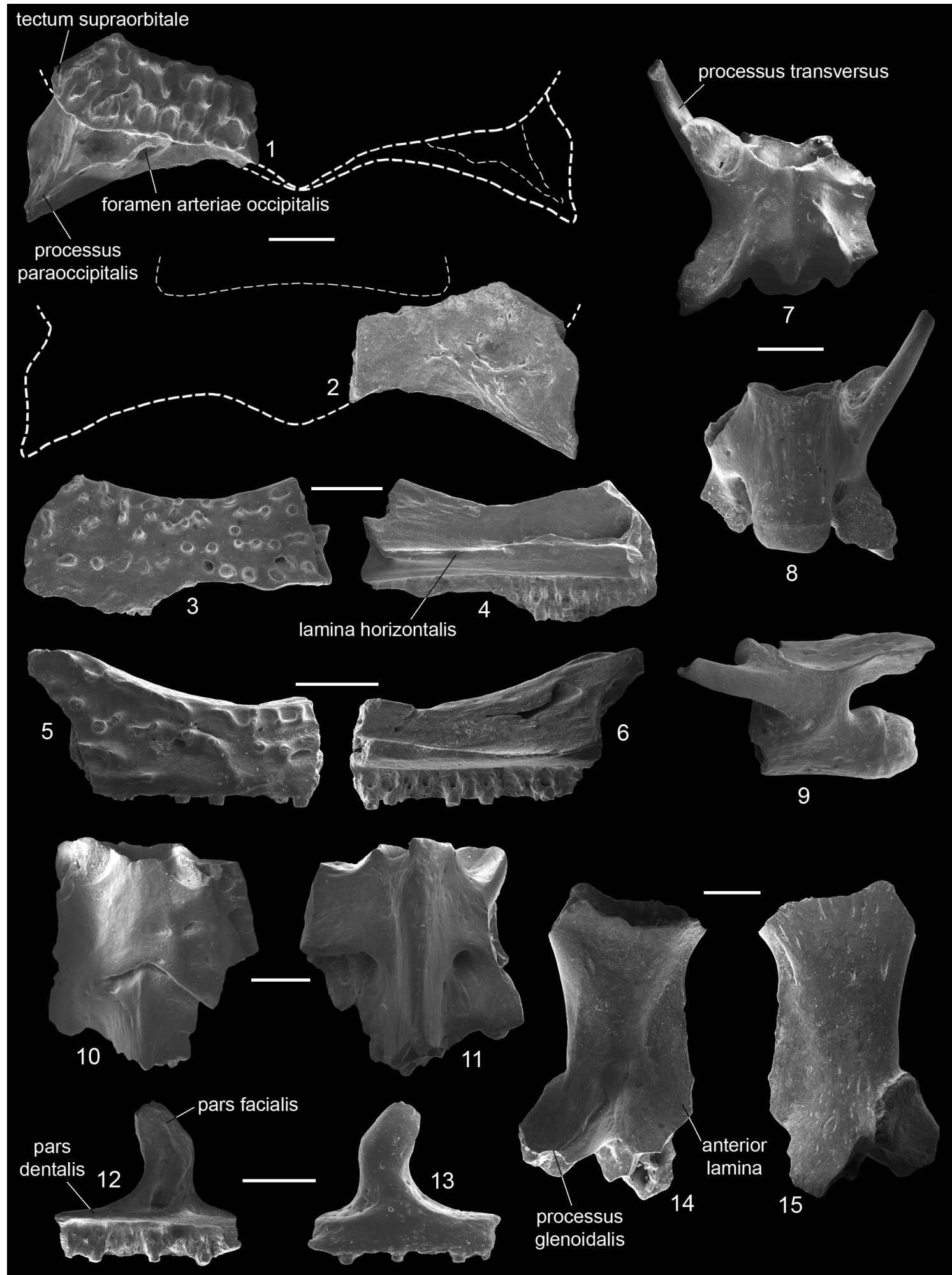

FIGURE 3. Pelobates sp. (1-11) and Pelobatidae indet. (12-15) from Volchaya Balka and Gaverdovsky localities, Russia (late Miocene, early Turolian). 1-2, frontoparietal (GIN 1143-223) in dorsal (1) and ventral (2) views; 3-4, left maxilla (GIN 1143-225) in labial (3) and lingual (4) views; 5-6, right maxilla (GIN 1143-226) in labial (5) and lingual (6) views; 7-9, presacral vertebra (GIN 1143-231) in dorsal (7), ventral (8), and lateral (9) views; 10-11, sacral vertebra (GIN 1144-201) in dorsal (10) and ventral (11) views; 12-13, premaxilla (GIN 1144-202) in lingual (12) and labial (13) views; and 14-15, left scapula (GIN 1143-233) in dorsal (14) and ventral (15) views. Scales equal $1 \mathrm{~mm}$. 
The scapula (Figure 3.14-15) lacks its acromial part and distal end. It is relatively robust, slightly curved and has a well-developed anterior lamina, which is concave along the anterior border. The posterior margin of the bone is only slightly concave. The processus glenoidalis is almost complete and well separated from the main corpus of the bone. The crista supraglenoidalis is massive and it is as long as the processus glenoidalis.

Comments. The described premaxilla shows the characteristics (i.e., narrow pars facialis positioned close to the midpoint of the pars dentalis), which generally correspond to some Eopelobates (e.g., E. anthracinus) and Pelobates. It differs from $E$. bayeri in which the pars facialis is close to medial end of the pars dentalis. This scapula has a broad and thin anterior lamina typical for Eopelobates, but such lamina may also be occasionally found in Pelobates, though developed to a lesser degree (Estes, 1970). Since there are no reliable characters in the premaxilla and scapula, which allow distinguishing Eopelobates and Pelobates, we refer the described bones to Pelobatidae indet.

\section{DISCUSSION}

The locality Volchaya Balka yielded skeletal remains which clearly represent both Eopelobates and Pelobates. In contrast, only Pelobates and indeterminate pelobatids were recovered from the locality Gaverdovsky. Because both localities yielded the same taxa of amphibians and reptiles, with the only difference of less numerous material in Gaverdovsky, it can be supposed that Eopelobates is not among the material from Gaverdovsky only because findings in this locality are less numerous.

Roček (2013) mentioned that although Eopelobates and Pelobates existed in Europe simultaneously, they rarely occurred in the same localities. However, both these genera were reported from the late Oligocene of Rott (Böhme et al., 1982), the early-middle Miocene of Sandelshausen (Böhme 2010), from the early Pliocene of Węże 1 and late Pliocene of Rębielice Królewskie 1 (Młynarski, 1977; Sanchíz and Młynarski, 1979), and from the early Pliocene of Ivanovce (Hodrová, 1981). The situation with the Pliocene records of Eopelobates is complicated by the fact that Eopelobates and Pelobates are distinguishable by their cranial osteology, whereas their postcranial elements are fairly similar (Roček, 2013; Rage, 2016). Consequently those records which are based exclusively on postcranial elements need verification. Moreover, ornamentation consisting of pits delimited by ridges on the frontoparietal of Eopelobates from Węże 1 (Sanchíz and Młynarski, 1979) was also observed in Pelobates from the Oligocene and Miocene (Venczel, 2004; Roček et al., 2014). Additional complication is that some published occurrences of Pliocene Eopelobates are dubious. For instance, the record of Eopelobates cf. bayeri from the late Pliocene of Gorishnaya Vygnanka (Ukraine), published by Tatarinov (1970), has never been described in full, and this determination was later questioned by Chkhikvadze (1984). Its large size and type of sculpture may indicate that it rather belongs to Latonia (Chkhikvadze, 1984; Roček, 1994). Another example of possible misidentification is the material from Dolinskoe and Odessa Catacombs-"western cave", both in Ukraine. It consists only of fragmentary maxillae and of postcranial elements, which were assigned to Eopelobates by Ratnikov (2002). However, the specimens were not adequately described, and state of their preservation prevents identification at the genus level.

Thus, the records of Pelobates and Eopelobates from Volchaya Balka represent, in addition to the above records from the late Oligocene through the Pliocene, further evidence of coexistence of both genera in a single locality, this time from the late Miocene. Besides, Eopelobates from Volchaya Balka is the first unambiguous record of the genus for Russia and the most eastern record of the genus in Europe (Figure 4). If the attribution to $E$. bayeri is confirmed, then this record extends stratigraphic occurrence of the species to the late Miocene.

The most distinctive feature of Pelobates from Volchaya Balka and Gaverdovskyis derived pustular sculpturing of the cranial bones. Within the genus Pelobates the forms with pit-and-ridge sculpture are known from the late Oligocene $(P$. decheni; Rott, MP 30, Germany; Böhme et al., 1982) to the middle and beginning of the late Miocene ( $P$. cf. sanchizi; Felsötárkány-Felnémet, $\mathrm{MN}$ 7+8-MN 9, Hungary; Venczel and Hír, 2013), whereas in the late Miocene forms (Pelobates sp.; Gritsev; MN 9, Ukraine; Roček et al., 2014), the sculpture is transitional between pit-and-ridge and pustular. Although the trends in cranial sculpture is unknown in pelobatids, its hypothetical transformation series based on fossils was suggested by Roček et al. (2014) from inferred primitive pit-andridge pattern (in Eocene-Pliocene Eopelobates and Oligocene-Miocene Pelobates), through transitional between pit-and-ridge and pustular pattern (in some Miocene Pelobates) to presumably 


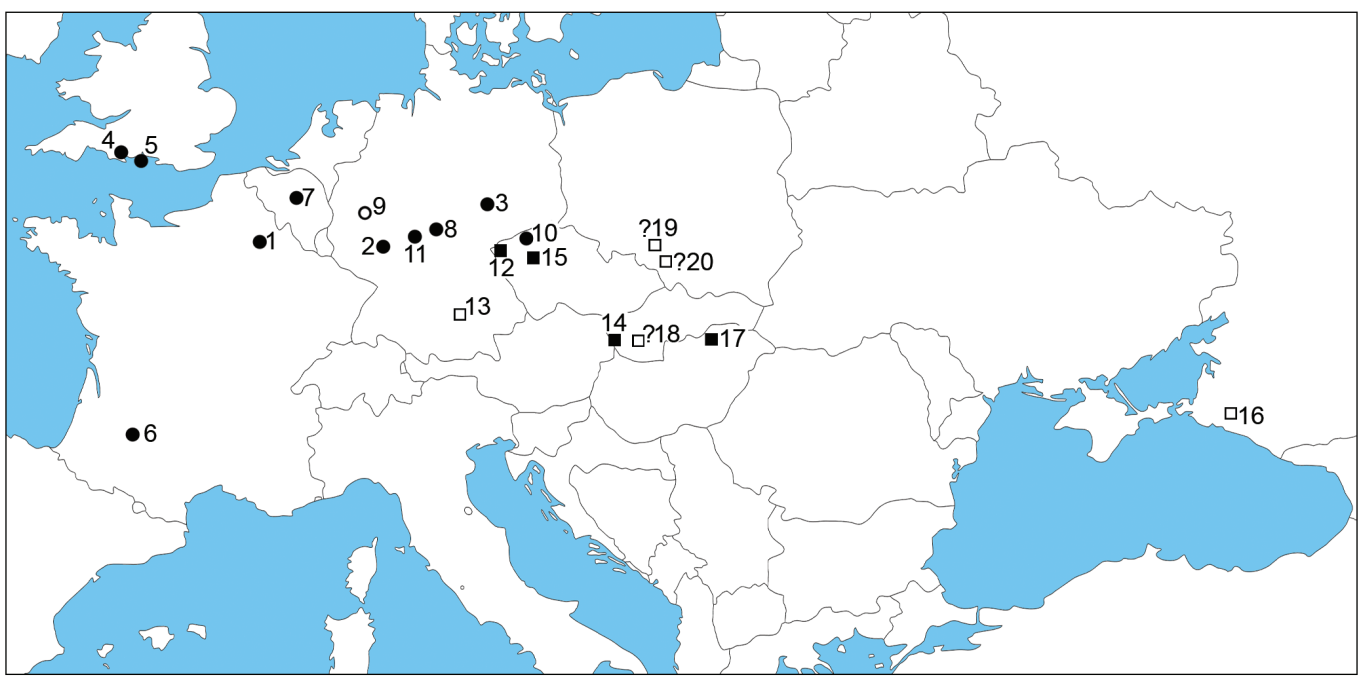

FIGURE 4. Occurrences of Eopelobates from the Paleogene (circles) and Neogene (squares) of Europe. Co-occurrences with Pelobates are indicated by open symbols. 1, Prémontré in France (Eopelobates aff. E. hinschei), MP 10, early Eocene (Duffaud, 2000); 2, Messel in Germany (E. wagneri), MP 11, middle Eocene (Wuttke, 2012); 3, Geiseltal in Germany (E. hinschei), MP 13, middle Eocene (Estes, 1970); 4, Hordle Cliff in UK (Eopelobates cf. E. hinschei), late Eocene (Milner et al., 1982); 5, Headon Hill in UK (cf. Eopelobates), late Eocene (Rage and Ford, 1980); 6, Quercy in France (cf. Eopelobates), late Eocene (Crochet et al., 1981); 7, Hoogbutsel, Hoeleden, and Boutersem TGV in Belgium (E. bayeri), MP 21, early Oligocene (Smith, 2003); 8, Sieblos in Germany (Eopelobates sp.), early Oligocene (Gaudant, 1985); 9, Rott in Germany (E. anthracinus), MP 30, late Oligocene (Parker, 1929); 10, Bechlejovice in Czech Republic (E. bayeri), late Oligocene (Špinar, 1952, 1972); 11, Oberleichtersbach in Germany (Eopelobates sp.), MP 30, late Oligocene (Böhme, 2008); 12, Dolnice in Czech Republic (Eopelobates sp.), MN 4, early Miocene (Hodrová, 1987b); 13, Sandelzhausen in Germany (Eopelobates sp.), MN 5, early Miocene (Böhme, 2010); 14, Devínska Nová Ves in Slovakia (E. bayeri), middle Miocene (Hodrová, 1988); 15, Suchomasty in Czech Republic (Eopelobates sp.), MN 10, late Miocene (Hodrová, 1987a); 16, Volchaya Balka in Russia (Eopelobates aff. E. bayeri), MN 11, late Miocene (this paper); 17, Osztramos 1 in Hungary (Eopelobates sp.), MN 14, Pliocene (Venczel, 2001); 18, ?lvanovce in Slovakia (?Eopelobates cf. bayeri), MN 15, Pliocene (Hodrová, 1981); 19, ?Węże 1 in Poland (Eopelobates sp.), MN 15, Pliocene (Młynarski, 1961, 1962; Sanchíz and Mlynarski, 1979); and 20, ?Rębielice Królewskie 1 in Poland (Eopelobates sp.), MN16, Pliocene (Sanchíz and Mlynarski, 1979). Data on taxonomic composition of Eopelobates are based mainly on Roček et al. (2014). The unconfirmed occurrences are denoted by a question-mark.

derived pustular sculpture (in Pliocene-Recent Pelobates). Roček et al. (2014) concluded that derived pustular sculpture is known only since the Pliocene. However, Pelobates from Volchaya Balka described in this paper brings the evidence that a typical pustular ornamentation appeared in this genus as early as in the late Miocene, at least during the Vallesian-Turolian ages.

Based on composition of herpetofauna, as well as the mammalian fauna and palynology (Tesakov et al., in press), the paleoenvironment of Volchaya Balka is generally reconstructed as wet and mainly forested area along shores of a large fresh-water basin under a warm temperate or subtropical climate. Eopelobates and Pelobates most probably prefer more open landscapes, which were not widespread near the burial of Volchaya Balka but still existed in the larger area as suggested by palynology. Though highly speculative, the presence in the assemblage of both Eopelobates and
Pelobates may indicate different ecological niches for these frogs. Little is known about fossoriality in Eopelobates and fossil Pelobates, but a hypothesis of non-fossorial mode of life of the former and at least incipient fossoriality of the latter should be tested in future.

\section{ACKNOWLEDGMENTS}

I would like to express my thanks to fellow members of the expeditions to the Volchaya Balka locality for collecting specimens, assistance in the field, and collaboration: V.V. Titov and S.V. Kurshakov (Institute of Arid zones, SSC RAS, Rostov-onDon, Russia), A.S. Tesakov and P.D. Frolov (Geological Institute, Russian Academy of Sciences, Moscow, Russia), N.V. Volkova (Paleontological Institute, Russian Academy of Sciences, Moscow, Russia), A.A. Lissovsky, E.V. Obolenskaya, and S.A. Tesakov (Moscow State University, Moscow, 
Russia), and I.A. Kazanov (Belaya Kalitva polytechnic technical school, Belaya Kalitva, Russia). I greatly appreciate the contribution of $\mathrm{M}$. Wuttke (Senckenberg Research Institute, Frankfurt, Germany) for providing literature about Eopelobates wagneri and two anonymous reviewers for useful comments and suggestion, which improved this paper. This research was supported by the Russian Foundation for Basic Research (Project 1504-02079_a); planned theme No. 00125-20160002.

\section{REFERENCES}

Bailon, S. 1991. Amphibiens et reptiles du Pliocène et du Quaternaire de France et d'Espagne: mise en place et évolution des faunes. Unpublished PhD Thesis, Université Paris 7, Paris, France.

Bailon, S. 1999. Différenciation ostéologique des Anoures (Amphibia, Anura) de France. Fiches d'ostéologie animale pour l'archéologie, Série C: varia. Centre de Recherches Archéologiques-CNRS, Valbonne, France.

Böhme, M. 2008. Ectothermic vertebrates (Teleostei, Allocaudata, Urodela, Anura, Testudines, Choristodera, Crocodylia, Squamata) from the Upper Oligocene of Oberleichtersbach (Northern Bavaria, Germany). Courier Forschungsinstitut Senckenberg, 260:161-183.

Böhme, M. 2010. Ectothermic vertebrates (Actinopterygii, Allocaudata, Urodela, Anura, Crocodylia, Squamata) from the Miocene of Sandelzhausen (Germany, Bavaria) and their implications for environment reconstruction and palaeoclimate. Paläontologische Zeitschrift, 84:3-41.

Böhme, W., Roček, Z., and Špinar, Z.V. 1982. On Pelobates decheni Troschel, 1861, and Zaphrissa eurypelis Cope, 1966 (Amphibia: Salientia: Pelobatidae) from the Early Miocene of Rott near Bonn, West Germany. Journal of Vertebrate Paleontology, 2:1-7.

Böhme, M. and Vasilyan, D. 2014. Ectothermic vertebrates from the late Middle Miocene of Gratkorn (Austria, Styria). Palaeobiodiversity and Palaeoenvironments, 94:21-40.

Bolkay, St.J. 1919. Osnove uporedne osteologije anurskih batrachija sa dodatkom o porijeklu Anura i sa skicom naravnog sistema istih. Glasnik Zemaljskog Muzeja Bosni Hercegovini, 31:353-377.

Bonaparte, C.L.J.L. 1850. Conspectus Systematum. Herpetologiae et Amphibiologiae. Editio Altera Reformata. Lugdini Batavorum: E.J. Brill, Leiden.

Chkhikvadze, V.M. 1984. Survey of the fossil urodelan and anuran amphibians in the USSR. Izvestia Akademii Nauk Gruzinska SSR, Seria Biologitcheskaya, 10:5-13. (In Russian, with English summary)

Crochet, J.Y., Hartenberger, J.-L., Rage, J.-C., Remy, J.A., Sige, B., Sudre, J., and Vianey-Liaud, M. 1981.
Les nouvelles faunes de vertebres anterieurs a la "Grande Coupure" decouverts dans les phosphorites du Quercy. Bulletin du Muséum d'Histoire naturelle, ser.4, 3(C):245-266.

Duffaud, S. 2000. Les faunes d'amphibiens du Crétacé supérieur à l'Oligocène inférieur en Europe: paléodiversité, évolution, mise en place. Unpublished $\mathrm{PhD}$ Thesis, Muséum National d'Histoire Naturelle, Paris, France.

Estes, R. 1970. New fossil pelobatid frogs and a review of the genus Eopelobates. Bulletin of the Museum of Comparative Zoology, 139:293-339.

Fischer, G. 1813. Zoognosia. Tabulis Synopticis Illustrata. In Usum Prælectionum Academiæ Imperialis Medico-Chirurgicæ Mosquensis Edita, third edition. Nicolai Sergeidis, Vsevolozsky, Moscow, Russia.

Frost, D.R., Grant, T., Faivovich, J., Bain, R.H., Haas, A., Haddad, C.F.B., De Sá, R.O., Channing, A., Wilkinson, M., Donnellan, S.C., Raxworthy, C.J., Campbell, J.A., Blotto, B.L., Moler, P., Drewes, R.C., Nussbaum, R.A., Lynch, J.D., Green, D.M., and Wheeler, W.C. 2006. The amphibian tree of life. Bulletin of the Natural History Museum, 297:1-370.

Gao, K. and Chen, J. 2017. A new crown-group frog (Amphibia: Anura) from the Early Cretaceous of northeastern Inner Mongolia, China. American Museum Novitates, 3876:1-39.

Gaudant, J. 1985. Mise au point sur les vertébrés inférieurs de l'Oligocene de Sieblos (Hesse, Allemagne). Comptes Rendus de l'Académie des Sciences, Paris, 300(2):185-188.

Henrici, A. 2002. Redescription of Eopelobates grandis, a late Eocene anuran from the Chadron Formation of South Dakota. Annals of Carnegie Museum, 71:241259.

Hodrová, M. 1981. Plio-Pleistocene frog fauna from Hajnáčka and Ivanovce, Czechoslovakia. Věstnik Ústředního Ústavu Geologického, 56(4):215-224.

Hodrová, M. 1987a. Amphibians from the Miocene sediments of the Bohemian Karst. Casopis Pro Mineralogii a Geologii, 32:345-356.

Hodrová, M. 1987b. Lower Miocene frogs from the Dolnice locality in the Cheb Basin (Czechoslovakia). Acta Universitatis Carolinae: Geologica, 1987:97115.

Hodrová, M. 1988. Miocene frog fauna from the locality Devínska Nová Ves - Bonanza. Věstnik Ústředního Ústavu Geologického, 63(5):305-310.

Ivanov, M. 2008. Early Miocene amphibians (Caudata, Salientia) from the Mokrá-Western Quarry (Czech Republic) with comments on the evolution of Early Miocene amphibian assemblages in Central Europe. Geobios, 41:465-492.

Khosatzky, L.I. 1985. A new species of spade-foot toads from the Pliocene of Moldavia, p. 59-72. In Negadaev-Nikonov, K.N. (ed.), Fauna and Flora of the Late Cenozoic of Moldavia. Shtiintsa, Kishinev. (In Russian) 
Kuhn, O. 1941. Die eozänen Anura aus dem Geiseltale nebst einer Übersicht über die fossilen Gattungen. Nova Acta Leopoldina, Neue Folge, 10(71):345-376.

Laurenti, J.N. 1768. Specimen Medicum, Exhibens Synopsin Reptilium Emendatum cum Experimentis Circa Venena et Antidota Reptilium Austriacorum. Wien, Austria.

Maus, M. and Wuttke, M. 2002. Comparative anatomical and taphonomical examination of the larvae of Pelobates decheni Troschel 1861 and Eopelobates anthracinus Parker 1929 (Anura: Pelobatidae) found at the Upper Oligocene sites at Enspel (Westerwald/ Germany) and Rott (Seibengebirge/Germany). Courier Forschungsinstitut Senckenberg, 237:129-138.

Maus, M. and Wuttke, M. 2004. The ontogenetic development of Pelobates cf. decheni tadpoles from the Upper Oligocene of Enspel (Westerwald/Germany). Neues Jahrbuch für Geologie und Paläontologie, 232:215-230.

Milner, A.C., Milner, A.R., and Estes, R. 1982. Amphibians and squamates from the Upper Eocene of Hordle Cliff, Hampshire - a preliminary report. Tertiary Research, 4:149-154.

Młynarski, M. 1961. Plazy (Amphibia) z pliocenu Polski. Acta Palaeontologica Polonica, 6:261-282.

Młynarski, M. 1962. Notes on the amphibian and reptilian fauna of the Polish Pliocene and early Pleistocene. Acta Zoologica Cracoviensia, 7:177-194.

Młynarski, M. 1977. New notes on the amphibian and reptilian fauna of the Polish Pliocene and Pleistocene. Acta Zoologica Cracoviensia, 22:13-36

Parker, H.W. 1929. Two fossil frogs of the lower Miocene of Europe. Annals and Magazine of Natural History, 10:270-281.

Rage, J.-C. 2016. Frogs (Amphibia, Anura) from the Eocene and Oligocene of the Phosphorites du Quercy (France). An overview. Fossil Imprint, 72(12):53-66.

Rage, J.-C. and Ford, R.L.E. 1980. Amphibians and squamates from the upper Eocene of the Isle of Wight. Tertiary Research, 3:47-60.

Rage, J.-C. and Roček, Z. 2003. Evolution of the anuran assemblages in the Tertiary and Quaternary of Europe, in context of palaeoclimate and palaeogeography. Amphibia-Reptilia, 24:133-167.

Ratnikov, V.Yu. 2002. Late Cenozoic Amphibians and squamate Reptiles of the East Europe Plain. Trudy Nauchno-Issledovatelskogo Instituta Geologii Voronezhskogo Universiteta, Voronezh, 10:1-138. (In Russian)

Roček, Z. 1981. Cranial anatomy of frogs of the family Pelobatidae Stannius, 1856, with outlines of their phylogeny and systematics. Acta Universitatis Carolinae, Biologica, 1980:1-164.

Roček, Z. 1994. Taxonomy and distribution of Tertiary discoglossids (Anura) of the genus Latonia v. Meyer, 1843. Geobios, 27:717-751.
Roček, Z. 2013. Mesozoic and Tertiary Anura of Laurasia. Palaeobiodiversity and Palaeoenvironments, 93:397-439.

Roček, Z. and Rage, J.-C. 2000. Tertiary Anura of Europe, Africa, Asia, North America, and Australia, p. 1332-1387. In Heatwole, H. and Carroll, R.L. (eds.), Amphibian Biology, 4, Paleontology. Surrey Beatty, Chipping Norton.

Roček, Z. and Wuttke, M. 2010. Amphibia of Enspel (Late Oligocene, Germany). Palaeobiodiversity and Palaeoenvironments, 90:321-340.

Roček, Z., Wuttke, M., Gardner, J.D., and Singh Bhullar, B.-A.S. 2014. The Euro-American genus Eopelobates, and a re-definition of the family Pelobatidae (Amphibia, Anura). Palaeobiodiversity and Palaeoenvironments, 94(4). doi:10.1007/s12549-014-0169-5

Sanchiz, B. 1998. Encyclopedia of Paleoherpetology, Part 4, Salientia. Verlag Dr. Friedrich Pfeil, München.

Sanchíz, B. and Młynarski, M. 1979. Remarks on the fossil anurans from the Polish Neogene. Acta Zoologica Cracoviensia, 24:153-173.

Smith, R. 2003. Les vertébrés terrestres de l'Oligocène inférieur de Belgique (Formation de Borgloon, MP 21): inventaire et interprétation des données actuelles. Coloquios de Paleontología, 1:647-657.

Špinar, Z.V. 1952 Eopelobates bayeri - a new frog from the Tertiary of Bohemia. Sborník Ústředniho ústavu geologického, 19:457-488.

Špinar, Z.V. 1972. Tertiary Frogs from Central Europe. Academia, Prague.

Špinar, Z.V. and Roček, Z.1984. The discovery of the impression of the ventral side of Eopelobates anthracinus Parker, 1929 holotype. Amphibia-Reptilia, 5:8795.

Syromyatnikova, E.V. 2016. Late Miocene anuran fauna from Volchaya Balka locality (north Caucasus, Russia), p. 224. In Holwerda, F., Madern, A., Voeten, D., van Heteren, A., Liston, J., Meijer, H., and den Ouden, N. (eds.), XIV Annual Meeting of the European Association of Vertebrate Palaeontologists. Haarlem, the Netherlands.

Tatarinov, K.A. 1970. Fauna of the Neogene Vertebrates. Unpublished PhD Thesis, University of Kiev, Kiev, Ukraine. (In Russian)

Tesakov, A.S., Titov, V.V., Simakova, A.N., Frolov, P.D., Syromyatnikova, E.V., Kurshakov, S.V., Volkova, N.V., Trichunkov, Y.I., Sotnikova, M.V., Kruskop, S.V., Zelenkov, N.V., Tesakova, E.M., and Palatov, D.M. In press. Late Miocene (early Turolian) vertebrate faunas and associated biotic record of the Northern Caucasus: geology, taxonomy, paleoenvironment, biochronology. Fossil Imprint, 73.

Tesakov, A.S, Titov, V.V., Syromyatnikova, E.V., Danilov, I.G., and Frolov, P.D. 2013. Biostratigraphy of the Upper Miocene deposits (Gaverdovsky Formation) in the valley of the Belaya River (North Caucasus) based on the faunas of terrestrial vertebrates and mollusks, p. 72-73. In Alekseev, A.S. (ed.), Paleostrat-2013. An Annual Meeting of Paleontological 
Section of MSN. Paleontological Institute of Russian Academy of Sciences, Moscow. (In Russian)

Troschel, F.H. 1861. Uebersicht aller bisher aus der Braunkohle des Siebengebirges beschriebenen fossilen Tiere etc. Sitzungsber Niederrheinischen Ges Bonn, 1861:55-56.

Venczel, M. 2001. Anurans and squamates from the Lower Pliocene (MN14) Osztramos 1 locality (northern Hungary). Fragmenta Palaeontologica Hungarica, 19:79-90.

Venczel, M. 2004. Middle Miocene anurans from the Carpathian Basin. Palaeontographica, Abteilung A, 271:151-174

Venczel, M. and Hír, J. 2013. Amphibians and squamates from the Miocene of Felsőtárkány Basin, NHungary. Palaeontographica, Abteilung, A, 300:117158.

Vinarski, M.V. and Frolov, P.D. 2016. A new late Miocene Lymnaea with aberrant suture structure unique for the family (Gastropoda: Pulmonata: Lymnaeidae). Historical Biology, 29(4):480-487.

Wagler, J. 1830. Natürliches System der Amphibien, mit vorangehender Classification der Säugthiere und Vogel. Ein Beitrag zur vergleichenden Zoologie. In der J.G. Cotta'scchen Buchhandlung, München.

Weitzel, K. 1938. Propelodytes wagneri n.g. n.sp., ein Frosch aus dem Mitteleozän von Messel. Notizblatt der Hessischen Geololgischen Landes-Anstalt (V), 19:42-46.

Wuttke, M. 2012. The genus Eopelobates (Anura, Pelobatidae) from Messel, Geiseltal, and Eckfeld (middle Eocene, Germany). Part I: Redescription of Eopelobates wagneri (Weitzel, 1938) from Messel (lower Geiseltalium, Germany). Kaupia-Darmstädter Beitr Naturgesch, 18:43-71.

Zweifel, R.G. 1956. Two pelobatid frogs from the Tertiary of North America and their relationships to fossil and recent forms. American Museum Novitates, 1762:145. 